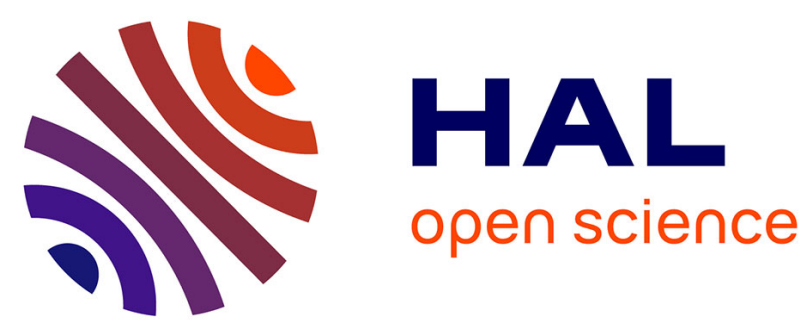

\title{
Shallow mixing of surface soil and liquid dairy manure conserves nitrogen while retaining surface residue
}

Quirine Ketterings, Greg Godwin, Peter Barney, Joseph Lawrence, Brian

Aldrich, Tom Kilcer, Karl Czymmek, Brent Gloy

\section{- To cite this version:}

Quirine Ketterings, Greg Godwin, Peter Barney, Joseph Lawrence, Brian Aldrich, et al.. Shallow mixing of surface soil and liquid dairy manure conserves nitrogen while retaining surface residue. Agronomy for Sustainable Development, 2013, 33 (3), pp.507-517. 10.1007/s13593-013-0141-1 . hal01201391

\section{HAL Id: hal-01201391 \\ https://hal.science/hal-01201391}

Submitted on 17 Sep 2015

HAL is a multi-disciplinary open access archive for the deposit and dissemination of scientific research documents, whether they are published or not. The documents may come from teaching and research institutions in France or abroad, or from public or private research centers.
L'archive ouverte pluridisciplinaire HAL, est destinée au dépôt et à la diffusion de documents scientifiques de niveau recherche, publiés ou non, émanant des établissements d'enseignement et de recherche français ou étrangers, des laboratoires publics ou privés. 


\title{
Shallow mixing of surface soil and liquid dairy manure conserves nitrogen while retaining surface residue
}

\author{
Quirine M. Ketterings • Greg Godwin • Peter Barney • \\ Joseph R. Lawrence • Brian Aldrich • Tom Kilcer • \\ Karl J. Czymmek • Brent Gloy
}

Accepted: 27 February 2013 / Published online: 11 April 2013

(C) INRA and Springer-Verlag France 2013

\begin{abstract}
Incorporation of spring-applied manure is known to reduce $\mathrm{N}$ volatilization losses and hence increase the $\mathrm{N}$ value of the manure. However, traditional incorporation methods are not compatible with reduced-tillage systems requiring minimum residue coverage of $30 \%$. Here, eight New York dairy farms participated in 2008 in a 2-year onfarm trial. This trial was designed to test the hypothesis that shallow mixing of soil involving aerator incorporation of spring-applied manure is as effective as chisel incorporation of manure in conserving manure $\mathrm{N}$ for corn (Zea mays, $\mathrm{L}$ ) uptake while retaining more surface residue. The eight fields selected for this trial varied from first to third year corn after hay and had varying manure histories. All fields were
\end{abstract}

\footnotetext{
Q. M. Ketterings $(\bowtie) \cdot$ G. Godwin $\cdot$ K. J. Czymmek

Nutrient Management Spear Program, Department of Animal

Science, Cornell University, 323 Morrison Hall,

Ithaca, NY 14853, USA

e-mail: qmk2@cornell.edu

P. Barney

Barney Agronomic Services, Potsdam, NY 13676, USA

J. R. Lawrence

Cornell Cooperative Extension of Lewis County, Lowville, NY

13367, USA

B. Aldrich

Cornell Cooperative Extension of Cayuga County, Auburn, NY

13021, USA

T. Kilcer

Advanced Ag Systems, Kinderhook, NY 12106, USA

B. Gloy

Department of Applied Economics and Management, Cornell University, Warren Hall,

Ithaca, NY 14853, USA
}

subjected to a randomized complete block design with four replicates comparing surface application of manure, as control, shallow incorporation of manure with an aerator, and chisel incorporation of manure. Starter N applications were $39 \mathrm{~kg} \mathrm{~N} / \mathrm{ha}$ or less, and manure application rates ranged from 51 to $112 \mathrm{~kL} / \mathrm{ha}$. Results show that shallow incorporation of manure significantly reduced soil disturbance and retained, on average, $30 \%$ more surface residue cover than obtained with chisel incorporation. Chisel and aerator-based incorporation resulted in similar soil nitrate levels at 13 of 16 site years, suggesting similar levels of $\mathrm{N}$ conservation. Across all sites and years, incorporation increased silage yield by $0.9-1.5 \mathrm{Mg} \mathrm{DM} / \mathrm{ha}$, independent of incorporation method. Based on these results, we show that shallow mixing of soil and spring-applied manure is a suitable option for conserving $\mathrm{N}$ and maintaining greater surface residue coverage without compromising on yield or silage quality.

Keywords Corn $\cdot$ Forage $\cdot$ Nitrogen $\cdot$ Nutrient management Nutrient cycling $\cdot$ Soil conservation $\cdot$ Tillage
Abbreviations
CSNT Corn stalk nitrate test
DM Dry matter
ISNT Illinois soil nitrogen test
PSNT Pre-sidedress nitrate test

\section{Introduction}

Environmental concerns associated with surface application of manure and rising costs of both $\mathrm{N}$ fertilizer and fuel have 
led many dairies in New York to spring-apply and incorporate manure for corn production, taking advantage of reductions in $\mathrm{P}$ runoff risk, and odor and ammonia $\mathrm{N}$ emission (Meisinger and Jokela 2000; Quincke et al. 2007), while benefitting from the soil improvement properties of manure (Nyiraneza et al. 2009).

When full incorporation with a moldboard plow is used, much of the remaining surface residue is mixed into the soil profile, leaving very little residue on the surface (Brown et al. 1992; Shapiro et al. 2001), negatively impacting soil quality (Maguire et al. 2011; Pierce et al. 1994). Chisel plows and disks can leave behind more surface residue than moldboard plowing while reducing the number of trips across a field (Oregon NRCS 2007; Maguire et al. 2011), but such semi-aggressive tillage equipment can still result in considerable loss of surface residue (Raper 2002; Shelton 2004). Shallow mixing of the surface soil with the manure using aerators is expected to result in less disturbance of the soil and greater residue coverage (Bittman et al. 2005; Harrigan et al. 2006; Maguire et al. 2011). Such aerators (Fig. 1), either solid-tine and core configurations, can, when set at an angle, lightly cultivate the surface soil and hence partially incorporate previously applied manure
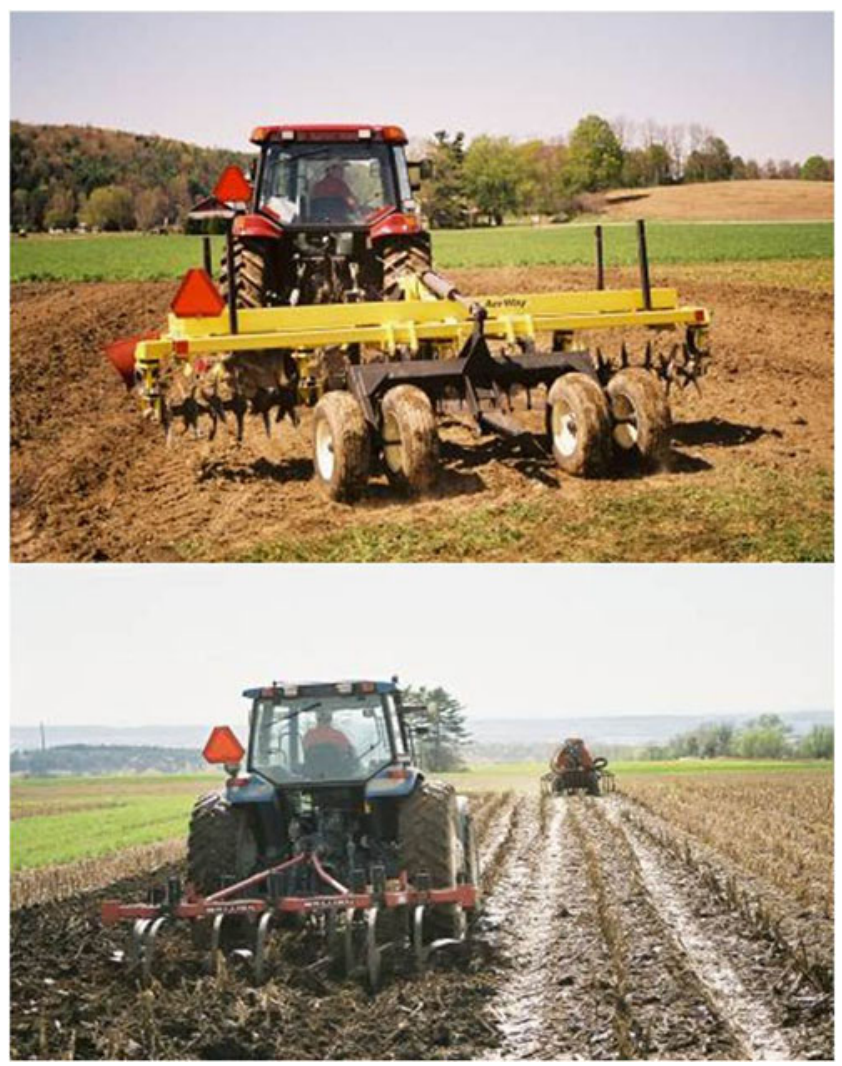

Fig. 1 Photographs of the manure incorporation methods, aerator and chisel
(Franklin et al. 2006, 2007; Lawrence et al. 2008; Maquire et al. 2011).

In situations where $\mathrm{N}$ limits crop production, spring incorporation of manure can result in higher corn yield (Klausner and Guest 1981; Lawrence et al. 2008). In a study by Lawrence et al. (2008), shallow incorporation of springapplied liquid dairy manure using an aerator within an hour after spreading was effective in conserving $\mathrm{N}$ and resulted in similar or higher corn grain yield than what was obtained after chisel incorporation of the manure. In contrast, Chen et al. (2001) reported no increase in yield as a result of aerator use before manure application on grasslands using liquid swine manure. Placement of the tillage operation (before or after manure application), aggressiveness of the tillage tool (angle), and timing of application will impact $\mathrm{N}$ conservation (Maguire et al. 2011), but research that quantifies this is scant.

The objectives of this study were to compare the impact of shallow incorporation (mixing) of spring-applied manure using aerator technology with that of chisel incorporation of manure and a no-incorporation control on (1) surface residue cover, (2) corn silage yield and forage quality, and (3) soil $\mathrm{N}$ conservation under farmer managed field conditions.

\section{Materials and methods}

\subsection{Site locations and experimental design}

Eight farm fields were selected by county extension educators and agronomic crop consultants to represent corn production areas throughout New York. Soil types ranged from silty clay loams to gravelly loams (Table 1). In 2008, the first year of the project, five of eight sites were second year corn, two were third year corn, and there was one first year corn site. Trials consisted of three treatments: (1) surface application of manure with no incorporation, (2) surface application of manure directly followed by chisel incorporation, and (3) surface application of manure directly followed by aerator incorporation. The trials were conducted using a complete randomized block design with three (one location) or four replications (seven locations). Plot sizes varied depending on farmer equipment and ranged from 12 to 20 rows wide (76-cm rows) and 91 to $213 \mathrm{~m}$ long with the inner six to ten rows harvested for yield measurements. There were planter problems that impacted the entire trial area at one of the locations in 2008 (resulting in a stand density of less than 46,000 plants/ha; Site 4) but for all other locations and years, stand densities ranged from about 77,000 to 87,000 plants/ha (Table 1). Fifteen of the 16 trials were harvested for corn silage. One location (Site 6) was harvested for grain in 2008. One location (Site 8) was seeded with a winter cover crop of cereal rye (Secale cereale 
Table 1 Site and field characteristics (soil type, rotation, initial sodium acetate extractable nitrate-N, P, and K) with manure application rates and corn stand density for 2008 and 2009

\begin{tabular}{|c|c|c|c|c|c|c|c|c|c|c|c|}
\hline \multirow[t]{2}{*}{ Site } & \multirow[t]{2}{*}{ County } & \multirow[t]{2}{*}{ Soil series } & \multicolumn{2}{|c|}{$\begin{array}{l}\text { Corn year in } \\
\text { rotation }\end{array}$} & \multicolumn{3}{|c|}{$\begin{array}{l}\text { Initial soil fertility in } 2008^{\mathrm{a}} \\
\left(\mathrm{mg} \mathrm{kg}^{-1}\right)\end{array}$} & \multicolumn{2}{|c|}{$\begin{array}{l}\text { Spreading rate } \\
\left(\mathrm{kL} \mathrm{ha}^{-1}\right)\end{array}$} & \multicolumn{2}{|c|}{$\begin{array}{l}\text { Stand density } \\
\left(\text { plants } \mathrm{ha}^{-1} \text { ) }\right.\end{array}$} \\
\hline & & & 2008 & 2009 & $\mathrm{~N}$ & $\mathrm{P}$ & $\mathrm{K}$ & 2008 & 2009 & 2008 & 2009 \\
\hline 1 & St. Lawrence & Muskellunge silt loam & 2 & 3 & 8 & $2 \mathrm{~L}$ & $33 \mathrm{~L}$ & 65.45 & 60.78 & 77,543 & 78,709 \\
\hline 2 & Columbia & Rhinebeck silt loam & 3 & 4 & 2 & $1 \mathrm{~L}$ & $28 \mathrm{~L}$ & 74.80 & 74.80 & 73,302 & 77,966 \\
\hline 3 & St. Lawrence & Hogansburg gravelly loam & 2 & 3 & 18 & $4 \mathrm{M}$ & $114 \mathrm{H}$ & 84.15 & 56.10 & 74,520 & 76,985 \\
\hline 4 & Chenango & Howard gravelly loam & 3 & 4 & 12 & $12 \mathrm{H}$ & $131 \mathrm{VH}$ & 77.61 & 81.81 & 45,927 & 79,408 \\
\hline 5 & Cayuga & Honeoye loam & 1 & 2 & 13 & $15 \mathrm{H}$ & $175 \mathrm{VH}$ & 65.45 & 112.20 & 66,986 & 87,117 \\
\hline 6 & Lewis & Amenia loam & 2 & 3 & 16 & $6 \mathrm{H}$ & $75 \mathrm{H}$ & 49.09 & 49.09 & 84,437 & 85,222 \\
\hline 7 & Clinton & Malone loam & 2 & 3 & 15 & $6 \mathrm{H}$ & $45 \mathrm{~L}$ & 84.15 & 84.15 & 76,928 & 77,474 \\
\hline 8 & Cayuga & Honeoye loam & 2 & 3 & 11 & $11 \mathrm{H}$ & $109 \mathrm{VH}$ & 74.80 & 74.80 & 74,969 & 78,339 \\
\hline
\end{tabular}

Extractable $\mathrm{P}$ and $\mathrm{K}$ are classified as $L=$ low, $M=$ medium, $H=$ high, and $V H=$ very high, depending on probability of an economic crop response according to Cornell University guidelines for corn management (Cornell Cooperative Extension 2013)

${ }^{\text {a }}$ Sodium acetate-extractable nitrate N, P, and K (Morgan 1941)

L.) in the fall preceding the incorporation treatments (Site 8 in 2008 and 2009).

\subsection{Field management}

Liquid dairy manure application rates varied from just above 49 to $112.2 \mathrm{~kL} \mathrm{ha}^{-1}$, but at most locations the targeted 65.5 $84.2 \mathrm{~kL} \mathrm{ha}^{-1}$ were applied (Table 1). The incorporation treatments were implemented within $1 \mathrm{~h}$ after manure application. The depth of incorporation ranged from 0.15 to 0 . $2 \mathrm{~m}$ for aeration set at a $15^{\circ}$ angle (maximum angle) and 0 . 25 to $0.35 \mathrm{~m}$ for chisel incorporation. Seedbed preparation took place five or more days after application to ensure ammonia volatilization from the surface-applied, nonincorporated manure. All sites were limited to $39 \mathrm{~kg} \mathrm{ha}^{-1}$ of $\mathrm{N}$ applied as a banded application in the starter fertilizer

Table 2 The total corn crop nutrients available $\left(\mathrm{N}, \mathrm{P}_{2} \mathrm{O}_{5}\right.$, and $\mathrm{K}_{2} \mathrm{O}$ in 2008/2009) at eight locations in the liquid dairy manure application study

\begin{tabular}{|c|c|c|c|c|c|c|c|c|c|c|}
\hline \multirow[t]{2}{*}{ Site } & \multirow[t]{2}{*}{ Treatment } & \multicolumn{3}{|c|}{ Manure nutrients available } & \multicolumn{3}{|c|}{ Fertilizer } & \multicolumn{3}{|l|}{ Total } \\
\hline & & $\mathrm{N}$ & $\mathrm{P}$ & $\mathrm{K}$ & $\mathrm{N}$ & $\mathrm{P}$ & K & $\mathrm{N}$ & $\mathrm{P}$ & $\mathrm{K}$ \\
\hline & & \multicolumn{9}{|c|}{$\mathrm{kg} \mathrm{ha}^{-1}(2008 / 2009)$} \\
\hline 1 & $\begin{array}{l}\text { Surface } \\
\text { Incorporation }\end{array}$ & $\begin{array}{l}38 / 31 \\
115 / 106\end{array}$ & $26 / 26$ & $138 / 127$ & $38 / 38$ & $7 / 7$ & $0 / 0$ & $\begin{array}{l}76 / 69 \\
153 / 144\end{array}$ & $33 / 34$ & $138 / 127$ \\
\hline 2 & $\begin{array}{l}\text { Surface } \\
\text { Incorporation }\end{array}$ & $\begin{array}{l}46 / 37 \\
122 / 116\end{array}$ & $34 / 33$ & $156 / 158$ & $24 / 22$ & $9 / 10$ & $23 / 0$ & $\begin{array}{l}69 / 59 \\
146 / 139\end{array}$ & $43 / 42$ & $179 / 158$ \\
\hline 3 & $\begin{array}{l}\text { Surface } \\
\text { Incorporation }\end{array}$ & $\begin{array}{l}35 / 17 \\
127 / 69\end{array}$ & $38 / 20$ & $211 / 82$ & $26 / 37$ & $5 / 0$ & $0 / 0$ & $\begin{array}{l}60 / 54 \\
152 / 106\end{array}$ & $44 / 20$ & $211 / 82$ \\
\hline 4 & $\begin{array}{l}\text { Surface } \\
\text { Incorporation }\end{array}$ & $\begin{array}{l}47 / 41 \\
101 / 141\end{array}$ & $50 / 40$ & $201 / 187$ & $34 / 0$ & $24 / 0$ & $9 / 0$ & $\begin{array}{l}81 / 41 \\
134 / 141\end{array}$ & $75 / 40$ & $210 / 187$ \\
\hline 5 & $\begin{array}{l}\text { Surface } \\
\text { Incorporation }\end{array}$ & $\begin{array}{l}19 / 39 \\
64 / 127\end{array}$ & $19 / 44$ & $117 / 200$ & $36 / 28$ & $15 / 0$ & $0 / 0$ & $\begin{array}{l}55 / 67 \\
100 / 155\end{array}$ & $34 / 44$ & $117 / 200$ \\
\hline 6 & $\begin{array}{l}\text { Surface } \\
\text { Incorporation }\end{array}$ & $\begin{array}{l}11 / 26 \\
52 / 73\end{array}$ & $19 / 20$ & $79 / 86$ & $0 / 0$ & $0 / 0$ & $0 / 0$ & $\begin{array}{l}11 / 26 \\
52 / 73\end{array}$ & $19 / 20$ & $79 / 86$ \\
\hline 7 & $\begin{array}{l}\text { Surface } \\
\text { Incorporation }\end{array}$ & $\begin{array}{l}35 / 7 \\
83 / 25\end{array}$ & $15 / 15$ & $99 / 95$ & $129 / 36$ & $26 / 24$ & $49 / 46$ & $\begin{array}{l}164 / 43 \\
212 / 60\end{array}$ & $41 / 39$ & $148 / 141$ \\
\hline 8 & $\begin{array}{l}\text { Surface } \\
\text { Incorporation }\end{array}$ & $\begin{array}{l}64 / 22 \\
129 / 104\end{array}$ & $30 / 29$ & $164 / 197$ & $34 / 34$ & $0 / 0$ & $0 / 0$ & $\begin{array}{l}97 / 56 \\
162 / 138\end{array}$ & $30 / 29$ & $164 / 197$ \\
\hline
\end{tabular}

Available $\mathrm{N}$ from manure assumes $35 \%$ availability of the organic $\mathrm{N}$ in the manure and $0 \%$ (surface application) or $65 \%$ availability of the ammonium-N fraction of the manure (incorporation with a chisel plow) 
with no sidedress fertilizer applications, except for one site in 2008 (Site 7) that was sidedressed with $129 \mathrm{~kg} \mathrm{ha}^{-1}$ of fertilizer N (Table 2). At most sites, the 2008 and 2009 growing seasons were wet, and in 2009, temperatures were also cooler than normal for June and July-resulting in a lower average corn yield for New York State $[15.8 \mathrm{Mg}$ dry matter (DM) ha ${ }^{-1}$ in 2008 versus $14.0 \mathrm{Mg} \mathrm{DM} \mathrm{ha}^{-1}$ in 2009; USDA-NASS 2010].

\subsection{Manure sampling and analysis}

A minimum of three manure samples were taken from the manure spreader at the time of application in each of the 2 years. Samples were kept cool while in the field and frozen upon arrival at the laboratory for later analysis. The samples were analyzed for total N (AOAC 2000a) and ammonia N (AOAC 2000b) at the DairyOne Forage Analysis Laboratory. The organic $\mathrm{N}$ was estimated as the difference between total $\mathrm{N}$ and ammonia N. Samples were analyzed for P and K content (Sirois et al. 1994), total solids (Hoskins et al. 2003), and density using a 51.5-ml standard vial (DairyOne 2007). Nutrient availability from the manure was estimated assuming $100 \%$ availability of $\mathrm{P}$ and $\mathrm{K}$ and $35 \% \mathrm{~N}$ available from the organic $\mathrm{N}$ fraction of the manure (Ketterings et al. 2003). Availability of $\mathrm{N}$ from the inorganic fraction was estimated assuming $0 \% \mathrm{~N}$ conservation for the unincorporated surface application and $65 \% \mathrm{~N}$ conservation for incorporation with a chisel plow (Ketterings et al. 2003).

\subsection{Surface residue}

Surface residue measurements were taken from 0 to 19 days after surface application of manure and incorporation treatment, varying by site and year due to practical limitations imposed by the large geographic distances among sites and weather in relationship to corn planting time. A 30-m rope with $0.3-\mathrm{m}$ indicators (100 marks) was used to determine residue coverage (Oregon NRCS 2007). Per plot, three measurements were taken by laying the rope diagonally across the plot and counting the number of marks that had corn or sod residue, or fresh cereal rye, or weed cover underneath. The three measurements were averaged to determine the percent surface residue cover for each treatment.

\subsection{Soil sampling}

Soil samples were taken for soil fertility and soil nitrate assessment at a depth of $0-20 \mathrm{~cm}$ four times during the growing season: (1) before manure application, (2) at planting, (3) when the corn was 0.15 to $0.30 \mathrm{~m}$ tall (4-6 leaf stage), and (4) at harvest. In addition, 0-30-cm soil samples were taken to determine the pre-sidedress nitrate test (PSNT). The sampling depth is standard depth of sampling for soil fertility testing, while the $0-30-\mathrm{cm}$ depth is required for PSNT sampling in New York (Klausner et al. 1993). Given that shallow and stony soils are common in New York, sampling to deeper depths is not practical. At each sampling time, 15 cores were taken per plot. Samples were kept cool while in the field and, upon arrival at the laboratory, placed in an oven $\left(50{ }^{\circ} \mathrm{C}\right)$ to dry for a minimum of $48 \mathrm{~h}$, prior to crushing to pass a 2-mm sieve. Gravimetric soil moisture was determined by weight loss of 2-mm sieved field-moist soil after drying in a $105{ }^{\circ} \mathrm{C}$ oven over night. Samples were analyzed for $\mathrm{pH}_{\text {water }}$, organic matter by losson-ignition (Storer 1984), and sodium acetate extractable N, P, K, (Morgan 1941) at the Cornell Nutrient Analysis Laboratory according to methods described in Wolf and Beegle (1995). The 0-0.30-m-depth samples were analyzed for the PSNT using the Morgan extraction per standard methodology (Morgan 1941). An Alpkem automated flow analyzer (RFA/2-320; OI Corporation, College Station, TX) was used to measure the Morgan extractable $\mathrm{NO}_{3}{ }^{-} \mathrm{N}$ and $\mathrm{PO}_{4}{ }^{-}-\mathrm{P}$ colorimetrically (Murphy and Riley 1962). Ammonium levels are typically low in the humid Northeast (Klapwyk et al. 2006) and were therefore not included in the measurements. Morgan extractable $\mathrm{K}$ was measured using a JY70 Type II ICP-AES (Jobin Yvon, Edison, NJ). The 0-20-cm-depth samples taken at PSNT time were also analyzed for the Illinois soil nitrogen test (ISNT) according to Khan et al. (2001) with the enclosed griddle modification (Klapwyk and Ketterings 2005). The ISNT has been accurate in separating fields with a high soil $\mathrm{N}$ supply potential from those with insufficient $\mathrm{N}$ supply for corn growth in studies in New York (Klapwyk and Ketterings 2006; Lawrence et al. 2009).

\subsection{End-of-season corn stalk nitrate test}

Fifteen stalks were sampled per plot at harvest. A $0.20-\mathrm{m}$ portion was cut from each stalk $0.15 \mathrm{~m}$ above the ground, following protocols outlined in Binford et al. (1990). Samples were placed in a $50{ }^{\circ} \mathrm{C}$ forced-air oven for a minimum of $48 \mathrm{~h}$ and then ground to pass a $2-\mathrm{mm}$ sieve prior to nitrate analysis. Stalks were analyzed for corn stalk nitrate test (CSNT)-N using $0.05 \mathrm{~mol} \mathrm{~L}^{-1} \mathrm{Al}_{2}\left(\mathrm{SO}_{4}\right)_{3}$ and a $2 \mathrm{~mol} \mathrm{~L}^{-1}\left(\mathrm{NH}_{4}\right)_{2} \mathrm{SO}_{4}$ ionic strength adjustor according to Wilhelm et al. (2000). A nitrate selective electrode and 710A pH/ISE meter (Thermo Scientific Orion, Waltham, MA) were used.

\subsection{Corn yield and forage quality}

Plots (inner six to eight rows) were harvested using the farmer's equipment, and wet weights were determined using farm scales, portable wheel load scales or yield monitors. A well-mixed subsample was taken per plot (3-4 L volume). The subsamples were kept cool while in the field and 
transferred to ovens upon arrival in the laboratory for moisture determination using a $50^{\circ} \mathrm{C}$ forced air oven for a minimum of $48 \mathrm{~h}$. Subsamples were analyzed at the Cumberland Valley Analytical Services, Inc. laboratory in Hagerstown, MD for crude protein (CP) (AOAC 2000a); soluble protein (Krishnamoorthy et al. 1982); neutral detergent fiber (30 h, NDF30; and 48 h, NDFD) (Van Soest et al. 1991), using Whatman 934-AH glass micro-fiber filters with $1.5 \mu \mathrm{m}$ particle retention modification; lignin (Goering and Van Soest 1970); starch (Holm et al. 1986); fat (AOAC 2006); and ash (AOAC 2000c), using $1.5 \mathrm{~g}$ sample weight with 4-h ash time. Estimated milk production per $\mathrm{Mg}$ and per hectare of corn silage was determined using Milk2006 with corn yield and $\mathrm{DM}, \mathrm{CP}, \mathrm{NDF}, \mathrm{NDFD}$, starch, fat, and ash as input variables (Shaver et al. 2006).

\subsection{Statistical analysis}

Data were analyzed using PROC MIXED (Littell et al. 1996) of the Statistical Analysis System (SAS Institute 1998). Each field and each year were analyzed individually due to site to site variability in field management histories, soil types and weather patterns, the potential for carryover of $\mathrm{N}$ benefits from manure applications in 2008 into 2009, and year to year weather differences. Manure application method was considered a fixed effect and blocks as random effect. A year analysis across all corn silage sites was done with manure application method and farm as fixed effects for each of the 2 years. This analysis was repeated for sites where silage CP from corn grown on the control plots (surface applied manure) was more than $70 \mathrm{~g} \mathrm{~kg}^{-1}$ and CSNT exceeded 5,000 $\mathrm{mg} \mathrm{kg}^{-1}$, essentially excluding locations where silage quality data indicated that $\mathrm{N}$ supply was not yield limiting. Where treatment effects were significant, mean separations were done using the LSMEANS procedure with TUKEY adjustment at $P \leq 0.05$.

\section{Results and discussion}

\subsection{Surface residue}

Both manure incorporation methods, aerator and chisel, reduced surface residue as compared to the unincorporated treatment (Fig. 2). Chisel plow incorporation of manure on fields with more than $20 \%$ residue cover reduced surface residue by $13-74 \%$ (with an average reduction of $41 \%$ ). A similar study by Coulter and Nafziger (2008), who compared chisel plowing with no-till following grain corn, reported a $25-40 \%$ reduction in surface residue cover upon chisel plowing with no or partial removal of the stover before tillage, an indication that chisel plowing can significantly reduce surface residue cover in low residue production systems.

Aerator incorporation resulted in less residue disturbance than chisel incorporation when unincorporated surface residue coverage exceeded $20 \%$ in our study. Aerator incorporation (maximum, $15^{\circ}$ angle) reduced surface residue by 9-53\% compared to no incorporation for fields where the initial surface residue cover exceeded $20 \%$. The impact of aeration on surface residue will depend on the angle of the aerator. Sexton et al. (2005) measured only minimal soil disturbance of 20-22\% from aeration (no angle) with a surface residue disturbance of $18-23 \%$ in barley stubble, stating that aeration met their low disturbance guidelines of $30 \%$ or less. Similar results were reported by Harrigan et al.
Fig. 2 Shallow mixing and incorporation of spring-applied liquid dairy manure using an aerator significantly reduced soil disturbance and retained, on average, $30 \%$ more surface residue cover than obtained with chisel incorporation of manure

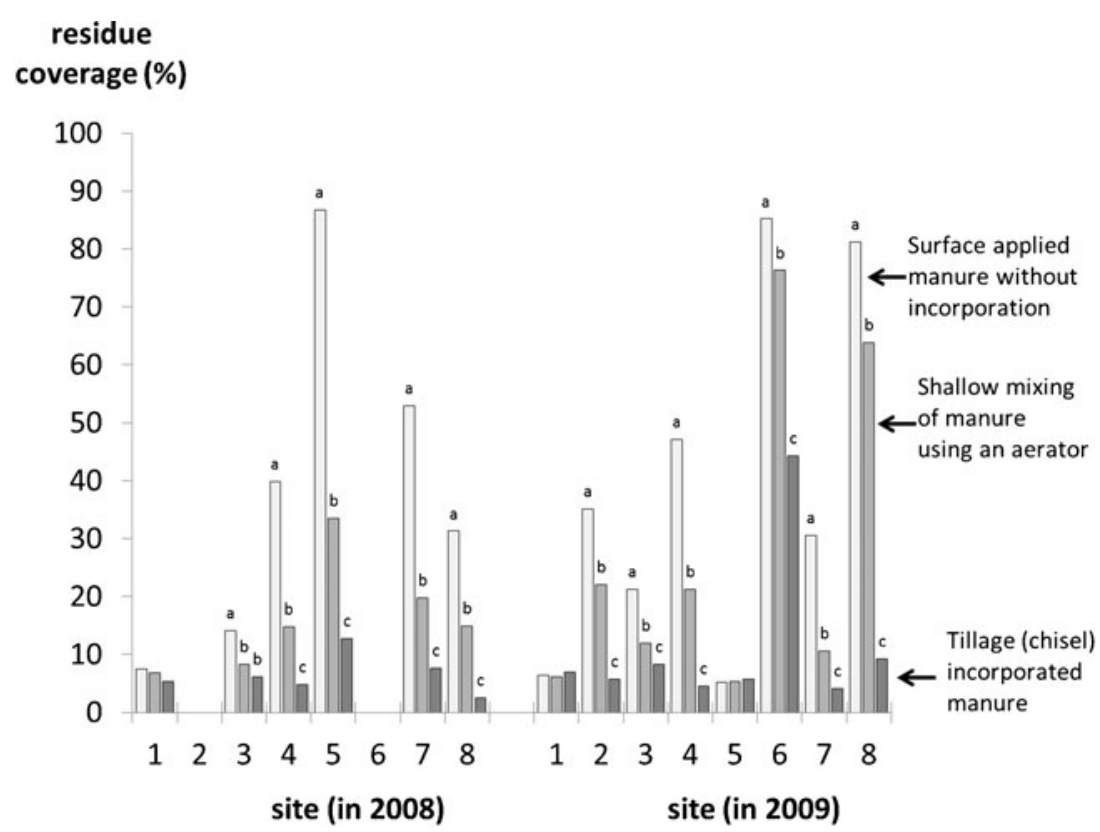


(2006) who measured a $14 \%$ reduction in surface residue cover after passing an aerator over wheat stubble $\left(10^{\circ}\right.$ angle $)$ residue when the field was aerated using a $0^{\circ}$ angle.

The NRCS defines conservation tillage as any system that can meet the $30 \%$ residue cover requirement after corn planting set by the Conservation Technology Information Center Core Conservation Practices (NRCS 1999). At three sites, residue coverage on the unincorporated manure treatment plot was greater than $60 \%$, attributable to previous cropping history. In these locations, residue cover levels exceeding $30 \%$ were obtained when the aerator was used to incorporate manure for first year corn after sod (Site 5, 2008), for corn silage after corn grain (Site 6, 2009), and if a cover crop was used (Site 8, 2009; poor stand in 2008), indicating potential for soil conservation with aerator incorporation if used in corn grain or after rotation into corn from sod or cover crops. Residue coverage measurements in our study were done at or after planting at 4 of 16 locations over the 2 years, while at the other locations, assessments took place before planting. It is unknown if planting impacted residue coverage, but from our results, it is clear that aerator incorporation of manure does conserve more residue than chisel plowing.

\subsection{Soil N, PSNT, CSNT}

Soil samples taken pre-manure application (baseline) in 2008 ranged in soil nitrate $\mathrm{N}\left(\mathrm{NO}_{3}-\mathrm{N}\right)$ from less than 2 to over $18 \mathrm{mg} \mathrm{kg}^{-1}$, reflecting site to site differences, consistent also with the range in ISNT-N values for the sites (Table 3). At all but two locations, soil nitrate levels prior to manure application exceeded $10 \mathrm{mg} \mathrm{kg}^{-1}$. The lowest nitrate levels were measured at sites that did not have a recent manure history and were low in P and $\mathrm{K}$ as well (Sites 1 and 2, Table 1). In 2009, baseline nitrate levels were less than $10 \mathrm{mg} \mathrm{kg}^{-1}$ for five of the eight locations, while only three locations (Sites 3,6, and 7) showed

Table 3 Soil nitrate levels in $(0-20 \mathrm{~cm}$ depth) taken at four different times (baseline-i.e., pre-manure application; at corn planting; at impacted by manure application method (surface application without incorporation versus direct incorporation with a chisel plow or aerator) sidedress time; and at harvest) for each site in 2008 and 2009 as

\begin{tabular}{|c|c|c|c|c|c|c|c|c|c|c|c|c|c|c|c|c|c|}
\hline \multirow{3}{*}{$\begin{array}{l}\text { Site } \\
1 \\
1\end{array}$} & \multirow{3}{*}{$\begin{array}{l}\text { Treatment } \\
\text { Surface }\end{array}$} & \multirow{3}{*}{$\begin{array}{l}\text { Year } \\
2008\end{array}$} & \multirow{3}{*}{$\begin{array}{l}\text { Baseline } \\
8.8\end{array}$} & \multicolumn{2}{|c|}{ Planting } & \multicolumn{2}{|l|}{ Sidedress } & \multicolumn{2}{|c|}{ Harvest } & \multirow{3}{*}{$\begin{array}{l}\text { Year } \\
2009\end{array}$} & \multirow{3}{*}{$\begin{array}{l}\text { Baseline } \\
7.5\end{array}$} & \multicolumn{2}{|c|}{ Planting } & \multicolumn{2}{|c|}{ Sidedress } & \multicolumn{2}{|c|}{ Harvest } \\
\hline & & & & \multicolumn{6}{|c|}{$\mathrm{mg} \mathrm{kg}^{-1} \mathrm{NO}_{3}-\mathrm{N}$} & & & \multicolumn{4}{|c|}{$\mathrm{mg} \mathrm{kg}^{-1} \mathrm{NO}_{3}-\mathrm{N}$} & & \\
\hline & & & & 30.5 & & 26.5 & & 4.0 & $\mathrm{~b}$ & & & 20.3 & & 26.3 & & 11.8 & \\
\hline & Chisel & & 7.4 & 36.4 & & 30.4 & & 9.3 & $\mathrm{a}$ & & 8.9 & 21.4 & & 28.9 & & 12.7 & \\
\hline & Aerator & & 8.4 & 36.5 & & 34.5 & & 7.9 & $\mathrm{a}$ & & 7.2 & 25.5 & & 30.5 & & 13.9 & \\
\hline \multirow[t]{3}{*}{2} & Surface & 2008 & 1.7 & 5.9 & & 20.5 & & 2.0 & & 2009 & 2.2 & 21.9 & $\mathrm{~b}$ & 29.0 & $\mathrm{~b}$ & 0 & \\
\hline & Chisel & & 1.9 & 5.2 & & 21.4 & & 0 & & & 4.4 & 21.2 & $\mathrm{~b}$ & 48.0 & $\mathrm{a}$ & 0 & \\
\hline & Aerator & & 2.7 & 4.9 & & 24.4 & & 0 & & & 2.2 & 31.2 & $\mathrm{a}$ & 39.9 & $a b$ & 0 & \\
\hline \multirow[t]{3}{*}{3} & Surface & 2008 & 16.9 & 34.4 & $\mathrm{~b}$ & 46.0 & & 18.7 & & 2009 & 11.2 & 28.4 & $\mathrm{~b}$ & 45.0 & & 9.8 & \\
\hline & Chisel & & 18.3 & 48.7 & $\mathrm{a}$ & 53.9 & & 26.5 & & & 15.7 & 46.8 & $\mathrm{a}$ & 57.7 & & 17.3 & \\
\hline & Aerator & & 16.7 & 42.9 & $a b$ & 45.7 & & 22.8 & & & 12.8 & 36.9 & $a b$ & 52.8 & & 11.0 & \\
\hline \multirow[t]{3}{*}{4} & Surface & 2008 & 10.2 & 14.4 & $\mathrm{~b}$ & 24.5 & $\mathrm{~b}$ & 12.9 & & 2009 & 1.4 & 15.3 & $\mathrm{~b}$ & 27.2 & $\mathrm{~b}$ & 7.3 & \\
\hline & Chisel & & 12.5 & 32.2 & $\mathrm{a}$ & 49.4 & $\mathrm{a}$ & 17.5 & & & 1.5 & 20.9 & $\mathrm{a}$ & 42.2 & $\mathrm{a}$ & 8.3 & \\
\hline & Aerator & & 11.9 & 22.5 & $a b$ & 31.4 & $a b$ & 14.5 & & & 2.7 & 15.7 & $\mathrm{a}$ & 39.3 & $\mathrm{a}$ & 7.2 & \\
\hline \multirow[t]{3}{*}{5} & Surface & 2008 & 12.4 & 33.4 & & 54.4 & & 18.4 & & 2009 & 6.9 & 39.7 & & 417 & & 12.8 & \\
\hline & Chisel & & 11.9 & 39.0 & & 67.5 & & 24.7 & & & 6.7 & 53.3 & & 53.8 & & 14.0 & \\
\hline & Aerator & & 13.8 & 39.7 & & 66.9 & & 18.4 & & & 5.4 & 39.2 & & 43.4 & & 12.0 & \\
\hline \multirow[t]{3}{*}{6} & Surface & 2008 & 15.9 & 43.0 & & $57.4 \mathrm{~b}$ & & . & & 2009 & 13.9 & 22.8 & & 29.0 & & 8.8 & \\
\hline & Chisel & & 16.2 & 51.5 & & $72.7 \mathrm{a}$ & & . & & & 12.3 & 28.5 & & 28.9 & & 10.7 & \\
\hline & Aerator & & 16.0 & 42.8 & & $62.3 \mathrm{ab}$ & & . & & & 11.8 & 27.9 & & 29.2 & & 9.7 & \\
\hline \multirow[t]{3}{*}{7} & Surface & 2008 & 14.8 & 21.3 & & 17.9 & & 10.2 & & 2009 & 13.5 & 14.9 & & 21.2 & & 13.2 & \\
\hline & Chisel & & 14.9 & 10.5 & & 16.0 & & 8.9 & & & 12.7 & 17.8 & & 26.5 & & 12.2 & \\
\hline & Aerator & & 14.3 & 19.5 & & 14.0 & & 11.0 & & & 13.5 & 17.7 & & 22.9 & & 12.2 & \\
\hline \multirow[t]{3}{*}{8} & Surface & 2008 & 10.8 & 20.3 & & 45.0 & & 8.7 & & 2009 & 6.9 & $19.7 \mathrm{~b}$ & & 17.3 & & 9.3 & $\mathrm{~b}$ \\
\hline & Chisel & & 11.2 & 31.9 & & 45.0 & & 11.0 & & & 5.2 & $39.3 \mathrm{a}$ & & 20.4 & & 14.8 & $\mathrm{a}$ \\
\hline & Aerator & & 10.5 & 27.5 & & 44.7 & & 9.3 & & & 6.3 & $25.5 \mathrm{~b}$ & & 19.5 & & 11.5 & $a b$ \\
\hline
\end{tabular}

Mean comparisons were done for each site and each year individually where the overall treatment effect was significant $(\alpha \leq 0.05)$. Means followed by a different letter $(\mathrm{a}, \mathrm{b})$ within a site and year are significantly different at $\alpha \leq 0.05$ 
levels between 10 and $16 \mathrm{mg} \mathrm{kg}^{-1}$ (Table 3), reflecting the relatively cold April of 2009 for most of the sites.

At planting, soil nitrate levels $(0-20 \mathrm{~cm}$ depth) tended to be lower where manure was surface-applied without incorporation as compared to chisel incorporation, but means were only significantly different at three of the eight locations in each of the 2 years (Sites 3, 4, and 8; Table 3). At sidedress time, means were significantly different at two of the eight sites in each of the 2 years (Sites 4 and 6 in 2008 and Sites 2 and 4 in 2009). Soil nitrate levels at harvest were lower with non-incorporated manure only at Site 1 in 2008 and at Site 8 in 2009.

There were no significant differences in soil nitrate levels between the aerator and chisel incorporation treatments at 62 of the 64 sampling times in 2008 and 2009 combined. Only one site (Site 8) showed higher soil nitrate levels at planting with chisel incorporation than with aerator incorporation in both years of the study (Table 4). The PSNT values ranged from 10 to $58 \mathrm{mg} \mathrm{kg}^{-1}$ in 2008. The PSNT values suggested a potential $\mathrm{N}$ deficiency $(\mathrm{PSNT} \leq$ $24 \mathrm{mg} \mathrm{kg}^{-1}$ ) for three sites (Sites 1, 2, and 7) when manure was surface applied and not incorporated and more than sufficient $\mathrm{N}$ for all other sites (Table 4). In 2009, PSNT values ranged from 10 to $50 \mathrm{mg} \mathrm{kg}^{-1}$. At two of the eight sites (Sites 3 and 5), the PSNT of plots where manure had been surface applied and not incorporated exceeded $24 \mathrm{mg} \mathrm{kg}^{-1}$, the critical value according to New York State PSNT interpretations (Ketterings et al. 2003).

Chisel incorporation of manure resulted in significantly higher PSNT than for aerator incorporation at one location in 2008 (Site 4) and another location in 2009 (Site 8). At these two locations, the aerator incorporation resulted in values no different from the PSNT results of surfaceapplied manure. There were no differences in PSNT between aerator and chisel plots at any of the other locations.

Table 4 Impact of surface application of manure, chisel incorporation of manure, and aerator incorporation (shallow mixing) of manure on the Illinois soil nitrogen test (ISNT), pre-sidedress nitrate test (PSNT), and end-of -season corn stalk nitrate test (CSNT) for eight sites in 2008 and 2009

\begin{tabular}{|c|c|c|c|c|c|c|c|c|c|c|c|c|c|}
\hline \multirow{3}{*}{$\begin{array}{l}\text { Site } \\
1\end{array}$} & \multirow{3}{*}{$\begin{array}{l}\text { Treatment } \\
\text { Surface }\end{array}$} & \multirow{3}{*}{$\begin{array}{l}\text { Year } \\
2008\end{array}$} & \multirow{3}{*}{$\begin{array}{l}\text { ISNT } \\
346\end{array}$} & \multicolumn{2}{|c|}{ PSNT } & \multicolumn{2}{|l|}{ CSNT } & \multirow{3}{*}{$\begin{array}{l}\text { Year } \\
2009\end{array}$} & \multirow{3}{*}{$\begin{array}{l}\text { ISNT } \\
372\end{array}$} & \multirow{2}{*}{\multicolumn{2}{|c|}{$\frac{\text { PSNT }}{\mathrm{mg} \mathrm{NO}_{3}-\mathrm{N} \mathrm{kg}^{-1}}$}} & \multicolumn{2}{|c|}{ CSNT } \\
\hline & & & & \multicolumn{4}{|c|}{$\mathrm{mg} \mathrm{NO}_{3}-\mathrm{N} \mathrm{kg}^{-1}$} & & & & & & \\
\hline & & & & 22.6 & $\mathrm{~b}$ & 191 & & & & 20.2 & & 419 & \\
\hline & Chisel & & 354 & 28.0 & $a b$ & 1095 & & & 395 & 22.8 & & 879 & \\
\hline & Aerator & & 383 & 32.8 & $\mathrm{a}$ & 840 & & & 378 & 21.9 & & 1029 & \\
\hline \multirow[t]{3}{*}{2} & Surface & 2008 & 211 & 9.7 & & 124 & $a b$ & 2009 & 211 & 20.9 & $\mathrm{~b}$ & 120 & \\
\hline & Chisel & & 208 & 17.0 & & 363 & $\mathrm{a}$ & & 217 & 33.5 & $\mathrm{a}$ & 151 & \\
\hline & Aerator & & 219 & 13.0 & & 108 & $\mathrm{~b}$ & & 222 & 29.4 & $\mathrm{ab}$ & 109 & \\
\hline \multirow[t]{3}{*}{3} & Surface & 2008 & 357 & 49.5 & & 8171 & & 2009 & 374 & 47.2 & & 5654 & \\
\hline & Chisel & & 378 & 48.0 & & 9845 & & & 362 & 51.0 & & 8209 & \\
\hline & Aerator & & 373 & 42.5 & & 8134 & & & 371 & 49.7 & & 8068 & \\
\hline \multirow[t]{3}{*}{4} & Surface & 2008 & 301 & 24.7 & $\mathrm{~b}$ & 2858 & $\mathrm{~b}$ & 2009 & 317 & 23.2 & $\mathrm{~b}$ & 250 & $\mathrm{~b}$ \\
\hline & Chisel & & 334 & 46.3 & $\mathrm{a}$ & 6392 & $\mathrm{a}$ & & 341 & 41.7 & $\mathrm{a}$ & 1150 & $\mathrm{a}$ \\
\hline & Aerator & & 320 & 26.9 & $\mathrm{~b}$ & 3545 & $\mathrm{~b}$ & & 328 & 31.4 & $\mathrm{ab}$ & 635 & $a b$ \\
\hline \multirow[t]{3}{*}{5} & Surface & 2008 & 216 & 40.5 & & 6131 & & 2009 & 229 & 38.8 & & 2240 & $\mathrm{~b}$ \\
\hline & Chisel & & 227 & 50.0 & & 6903 & & & 236 & 44.7 & & 4287 & $\mathrm{a}$ \\
\hline & Aerator & & 223 & 50.5 & & 6458 & & & 238 & 38.9 & & 2848 & $a b$ \\
\hline \multirow[t]{3}{*}{6} & Surface & 2008 & 466 & 57.9 & & 2535 & & 2009 & 489 & 18.4 & & 227 & \\
\hline & Chisel & & 472 & 57.8 & & 2751 & & & 477 & 18.2 & & 332 & \\
\hline & Aerator & & 471 & 57.9 & & 1795 & & & 487 & 17.2 & & 200 & \\
\hline \multirow[t]{3}{*}{7} & Surface & 2008 & 355 & 12.5 & & 30 & & 2009 & 314 & 19.8 & & 52 & \\
\hline & Chisel & & 351 & 12.8 & & 9 & & & 296 & 14.5 & & 48 & \\
\hline & Aerator & & 363 & 13.0 & & 21 & & & 307 & 9.7 & & 50 & \\
\hline \multirow[t]{3}{*}{8} & Surface & 2008 & 243 & 36.4 & & 5432 & & 2009 & 250 & 14.9 & $\mathrm{~b}$ & 1126 & $\mathrm{~b}$ \\
\hline & Chisel & & 239 & 42.6 & & 8167 & & & 237 & 21.8 & $\mathrm{a}$ & 3407 & $\mathrm{a}$ \\
\hline & Aerator & & 245 & 40.5 & & 4516 & & & 247 & 16.7 & $\mathrm{~b}$ & 1330 & $\mathrm{~b}$ \\
\hline
\end{tabular}

A PSNT $<21 \mathrm{mg} \mathrm{kg}^{-1}$ is nitrate deficient and PSNT $\geq 25 \mathrm{mg} \mathrm{kg}^{-1}$ is nitrate sufficient; CSNT $<250 \mathrm{mg} \mathrm{kg}^{-1}$ indicates additional N was needed, $250-750 \mathrm{mg} \mathrm{kg}^{-1}$ indicates $\mathrm{N}$ was marginal, $750-2,000 \mathrm{mg} \mathrm{kg}^{-1}$ indicates $\mathrm{N}$ was optimal, $>2,000 \mathrm{mg} \mathrm{kg}^{-1}$ indicates $\mathrm{N}$ was available in excess of crop needs. Mean comparisons were done for each site and each year individually where the overall treatment effect was significant $(\alpha \leq 0.05)$. Means followed by a different letter $(\mathrm{a}, \mathrm{b})$ within a site and year are significantly different at $\alpha \leq 0.05$ 
Table 5 Corn silage yield (DM, dry matter), forage quality (crude protein, soluble protein, neutral detergent fiber (NDF), 48-h digestibility of NDF (NDFD), lignin, and starch), and milk production estimates for 2008 and 2009 at each site as impacted by surface application of liquid dairy manure, chisel incorporation of manure, and aerator incorporation (shallow mixing) of manure

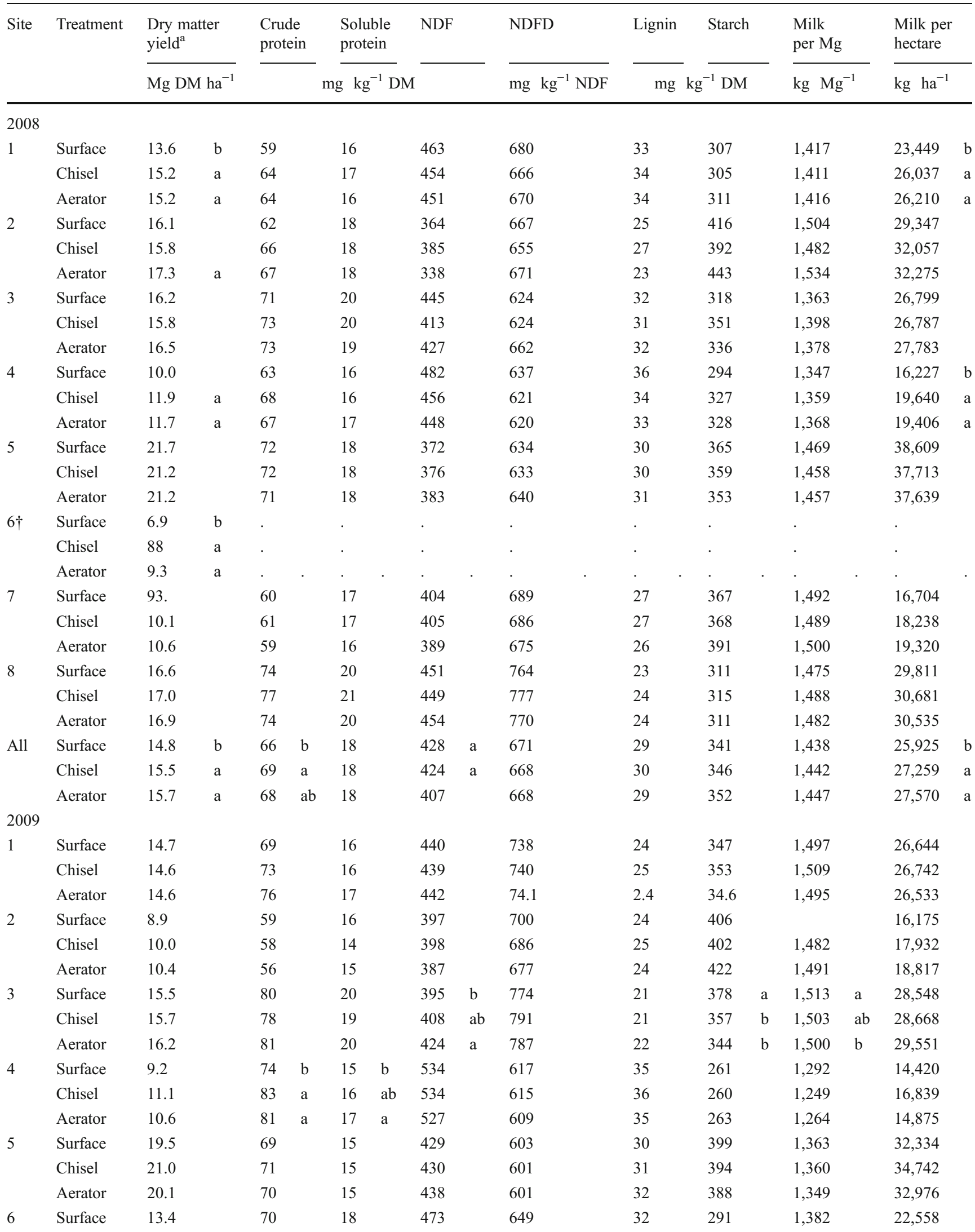


Table 5 (continued)

\begin{tabular}{|c|c|c|c|c|c|c|c|c|c|c|c|}
\hline \multirow[t]{2}{*}{ Site } & \multirow[t]{2}{*}{ Treatment } & \multicolumn{2}{|c|}{$\begin{array}{l}\text { Dry matter } \\
\text { yield }^{\mathrm{a}}\end{array}$} & $\begin{array}{l}\text { Crude } \\
\text { protein }\end{array}$ & $\begin{array}{l}\text { Soluble } \\
\text { protein }\end{array}$ & NDF & NDFD & Lignin & Starch & \multirow{2}{*}{$\begin{array}{l}\begin{array}{l}\text { Milk } \\
\text { per Mg }\end{array} \\
\mathrm{kg} \mathrm{Mg}^{-1}\end{array}$} & \multirow{2}{*}{$\begin{array}{l}\text { Milk per } \\
\text { hectare }\end{array}$} \\
\hline & & \multicolumn{2}{|c|}{$\mathrm{Mg} \mathrm{DM} \mathrm{ha}{ }^{-1}$} & \multicolumn{3}{|c|}{$\mathrm{mg} \mathrm{kg}^{-1} \mathrm{DM}$} & $\mathrm{mg} \mathrm{kg}^{-1} \mathrm{NDF}$ & \multicolumn{2}{|c|}{$\mathrm{mg} \mathrm{kg}^{-1} \mathrm{DM}$} & & \\
\hline \multirow{5}{*}{7} & Chisel & 14.3 & & 69 & 18 & 474 & 664 & 31 & 294 & 1,399 & 24,282 \\
\hline & Aerator & 14.9 & & 70 & 18 & 477 & 651 & 32 & 285 & 1,381 & 24,972 \\
\hline & Surface & 6.7 & & 63 & 16 & 455 & 790 & 22 & 271 & 1,439 & 11,628 \\
\hline & Chisel & 7.3 & & 65 & 17 & 446 & 787 & 22 & 283 & 1,464 & 12,975 \\
\hline & Aerator & 7.6 & & 64 & 17 & 452 & 788 & 23 & 267 & 1,431 & 13,288 \\
\hline \multirow[t]{3}{*}{8} & Surface & 17.9 & & 71 & 19 & 388 & 660 & 27 & 378 & 1,497 & 32,529 \\
\hline & Chisel & 19.3 & & 73 & 19 & 398 & 657 & 29 & 362 & 1,482 & 34,640 \\
\hline & Aerator & 18.7 & & 71 & 19 & 392 & 652 & 28 & 373 & 1,481 & 33,760 \\
\hline \multirow[t]{3}{*}{ All } & Surface & 13.2 & $\mathrm{~b}$ & 69 & 17 & 439 & 691 & 27 & 342 & 1,435 & 23,115 \\
\hline & Chisel & 14.1 & $\mathrm{a}$ & 71 & 17 & 437 & 693 & 27 & 338 & 1,432 & 24,574 \\
\hline & Aerator & 14.0 & $\mathrm{a}$ & 71 & 17 & 440 & 689 & 28 & 336 & 1,424 & 24,320 \\
\hline
\end{tabular}

Season average yields were based on corn silage yields only. Mean comparisons were done for each site and each year individually and across all sites. Means followed by a different letter ( $\mathrm{a}, \mathrm{b}$ ) within a site (or for all sites together) are significantly different at $\alpha \leq 0.05$

${ }^{a}$ Corn was harvested for grain in 2009 at farm 6 versus silage for all other sites and years

The 2008 CSNT results ranged from 9 to almost $10,000 \mathrm{mg} \mathrm{NO}-\mathrm{N} \mathrm{kg}^{-1}$. At five locations that year, CSNT results suggested excess $\mathrm{N}\left(>2,000 \mathrm{mg} \mathrm{kg}^{-1}\right.$; Table 4). These were the same five locations with PSNTs exceeding $24 \mathrm{mg} \mathrm{kg}^{-1}$. In 2009, CSNT samples ranged from approximately 50 to $8,000 \mathrm{mg} \mathrm{kg}^{-1}$. That year two of the eight sites were classified as excessive in $\mathrm{N}$ supply based on CSNT results and consistent with the PSNT data (Sites 3 and 5). In general, CSNT results were considerably lower in 2009 than in 2008. There were no significant differences in CSNT between chisel and aerator incorporation at 13 of the 16 site years, while at the remaining three site years, chisel incorporation resulted in significantly higher CSNT, consistent with the higher PSNT values for the chisel incorporation treatment at two of these three sites.

\subsection{Corn yield, forage quality, and $\mathrm{N}$ conservation}

There were no significant yield differences between plots where manure was shallowly mixed with soil using the aerator and plots where manure had been incorporated with a chisel plow (Table 5). In 2008, the two incorporation treatments resulted in significantly higher yields than the surface application at three of the eight locations, while at several other locations a similar trend was seen. Across all locations, an average yield increase of $0.8 \mathrm{Mg} \mathrm{ha}^{-1}$ was obtained with incorporation of manure, independent of the method of incorporation. In 2009, there were no significant yield differences among the incorporation treatments and surface application for any of the individual sites, but across all sites, incorporation of manure resulted in a significant 0 . $9 \mathrm{Mg} \mathrm{ha}^{-1}$ increase in yield.

In 2008, manure application method did not impact silage quality for any of the sites (Table 5). Differences in milk per hectare estimates reflected silage yield differences only. In 2009, surface application resulted in a reduction in CP for one of the eight locations, while at another location, a slight reduction in NDF was measured. A slight reduction in starch was measured at one of the sites for the incorporation treatments, with significant mean differences in milk production per $\mathrm{Mg}$ of silage for aerator incorporation in comparison to surface application. These forage quality differences did not significantly impact the overall milk production estimates per hectare for 2009.

The 2 years showed very different growing conditions. The 2009 growing season was characterized as cold and wet. The 2008 growing season allowed for higher yields due to warmer and less saturated conditions. These seasonal differences are reflected in soil nitrate, CSNT, and yield data. For example, across all sites and treatments, silage yield averaged $1.6 \mathrm{Mg} \mathrm{ha}^{-1}$ less in 2009 than in 2008. The PSNT results did not necessarily reflect the wetter 2009 season as a considerable amount of precipitation occurred after sampling for PSNT.

The lack of a yield response at several individual sites indicates $\mathrm{N}$ was not limiting production, and this was confirmed by PSNT, CP, and CSNT levels. When the three sites that had CP levels of $70 \mathrm{~g} \mathrm{~kg}^{-1}$ or higher and CSNT over $5,000 \mathrm{mg} \mathrm{kg}^{-1}$ were excluded from the average yield calculation across sites, yield with surface application of manure averaged 12.2 $\mathrm{Mg} \mathrm{ha}^{-1}$, versus $13.7 \mathrm{Mg} \mathrm{ha}^{-1}$ for aerator or 
chisel incorporation. This $1.5-\mathrm{Mg} \mathrm{ha}{ }^{-1}$ yield difference was once again independent of incorporation method, further supporting the hypothesis that shallow mixing is equally effective in conserving $\mathrm{N}$ as chisel plowing and that incorporation results in a yield increase where $\mathrm{N}$ is limiting production. Despite the weather-impacted lower yields in 2009, a similar trend was seen that year: without the four sites that had CP levels of $70 \mathrm{mg} \mathrm{kg}^{-1}$ or higher that year, yields averaged 12.6 $\mathrm{Mg} \mathrm{ha}^{-1}$ with surface application without incorporation versus 13.4 and $13.5 \mathrm{Mg} \mathrm{ha}^{-1}$ for chisel and aerator incorporation, respectively. These yield results are consistent with data reported by Lawrence et al. (2008) that showed no yield penalty for shallow incorporation with an aerator as compared to chisel plowing of spring-applied manure in 2 of 3 years in the study, with higher yield with aerator incorporation than with chisel plow incorporation in the third year of the study, a dry planting season. Few studies on application methods have been done with corn, but the literature includes several studies with grass. Consistent with our results, Bittman et al. (2005) reported an overall yield increase of $4.4 \%$ for tall fescue (Festuca arundinacea Schreb.) and orchardgrass (Dactylis glomerata L.) when liquid dairy manure was surface banded directly over aeration slots compared to just surface banding manure. In contrast, Chen et al. (2001) did not report a grass yield difference due to aeration before swine manure application. The differences seen in these two studies may be attributed to the degrees of tillage angle as Bittman et al. (2005) utilized a $2.5^{\circ}$ angle for aeration to reduce soil disturbance and yield losses in comparison to a $15^{\circ}$ aeration angle utilized by Chen et al. (2001) to maximize manure infiltration. The latter could have resulted in stand damage, offsetting a potential yield response due to greater manure $\mathrm{N}$ use efficiency. The corn study by Lawrence et al. (2008) and our eight-farm study were conducted by spreading liquid manure before aeration at a $15^{\circ}$ angle so as to incorporate the manure quickly and to provide better mixing of the manure with the surface soil. The results indicate that such shallow mixing after manure spreading conserved $\mathrm{N}$ as compared to leaving manure on the surface.

\section{Conclusions}

Shallow incorporation of manure resulted in greater surface residue conservation compared to chisel incorporation with no measurable impact on soil compaction. Manure N conservation was similar for both incorporation treatments and resulted in a $0.9-1.5 \mathrm{Mg} \mathrm{ha}^{-1}$ yield increase across all sites. The additional $\mathrm{N}$ from manure incorporation did not increase corn yields where $\mathrm{N}$ supply was already sufficient as illustrated by a CSNT of $5,000 \mathrm{mg} \mathrm{kg}^{-1}$ or higher and CP levels of $70 \mathrm{mg} \mathrm{kg}^{-1}$ or higher for corn grown on plots where manure had not been incorporated. We conclude that shallow incorporation of manure is a suitable alternative to chisel incorporation in reduced tillage systems for reducing $\mathrm{N}$ volatilization from manure and maintaining surface residue cover.

Acknowledgments The authors thank Anne Place, Kevin Dietzel, Chie Miyomoto, Patty Ristow, Sarah Wharton, Eun Hong, Hillary Bundick, John Weiss, and Sanjay Gami for their help with data collection in the field and in the laboratory. We thank Peg Cook (Cooks Consulting) for help with field history data collection and cooperating producers Jake Ashline (Miner Institute), Darren McIntyre (Wyndamar Farms), Dave Fisher (Mapleview Dairy LCC), Dan Chambers (Chambers Farm LCC), Brian Chittenden (Dutch Hollow Farm LCC), Martha and Richard Place (Hohl Acres), Neil and Greg Rejman (Sunnyside Farm, Inc), and Bill Kilcer (Winnstott Farm) for working with us on the trials and donating time and equipment to the project. This project was funded by grants from the New York Farm Viability Institute (NYFVI), Northern New York Agricultural Development Program (NNYADP), in-kind contributions by Cornell Cooperative Extension, the College of Agriculture and Life Science, the consultants and the farmers.

\section{References}

AOAC (2000a) Protein (crude) in animal feed. AOAC-990.03. In: Official methods of analysis of the Association of Official Analytical Chemists, 17th edn. AOAC, Arlington

AOAC (2000b) Urea and ammoniacal nitrogen in animal feed. AOAC 941.04. In: Official methods of analysis of the Association of Official Analytical Chemists, 17th edn. AOAC, Arlington

AOAC (2000c) Ash of animal feed. AOAC-942.05. In: Official methods of analysis of the Association of Official Analytical Chemists, 17th edn. AOAC, Arlington

AOAC (2006) Crude fat in feds, cereal grains and forages. AOAC2003.05. In: Official methods of analysis of the Association of Official Analytical Chemists, 18th edn. AOAC, Arlington

Binford GD, Blackmer AM, El-Hout NM (1990) Tissue test for excess nitrogen during corn production. Agron J 82:124-129. doi:10.2134/agronj1990.00021962008200010027x

Bittman S, van Vliet LJP, Kowalenko CG, McGinn S, Hunt DE, Bounaix F (2005) Surface banding liquid manure over aeration slots: a new low-disturbance method for reducing ammonia emissions and improving yield of perennial grasses. Agron J 97:13041313. doi:10.2134/agronj2004.0277

Brown LC, Wood RK, Smith JM (1992) Residue management demonstration and evaluation. Appl Eng Agric 8:333-339

Chen Y, Zhang Q, Petkau DS (2001) Evaluation of different techniques for liquid manure application on grassland. Appl Eng Agric 17:489-496

Cornell Cooperative Extension (2013) 2013 Cornell Guide for integrated field crop management. Cornell University, Ithaca, NY. Available at: http://www.fieldcrops.org/ Verified 9 Feb 2013

Coulter JA, Nafziger ED (2008) Continuous corn response to residue management and nitrogen fertilizer. Agron J 100:1774-1780. doi:10.2134/agronj2008.0170

DairyOne (2007) Forage laboratory services - procedures VI. Manure. Available at: http://www.dairyone.com/Forage/procedures/ Verified 9 Feb 2013

Franklin DH, Cabrera ML, Calvert VH (2006) Fertilizer source and soil aeration effects on runoff volume and quality. Soil Sci Soc Am J 70:84-89. doi:10.2136/sssaj2003.0114 
Franklin DH, Cabrera ML, West LT, Calvert VH, Rema JA (2007) Aerating grasslands: effects of runoff and phosphorus losses from applied broiler manure. J Environ Qual 36:208-215. doi:10.2134/ jeq2006.0012

Goering HK, Van Soest PJ (1970) Forage fiber analysis (apparatus, reagents, procedures, and some applications). Agric Handb 379. U.S. Gov. Print. Office, Washington, DC

Harrigan TM, Bailey BB, Northcott WJ, Kravchenko AN, Laboski CAM (2006) Field performance of a low-disturbance, rolling-tine dribble-bar manure applicator. Appl Eng Agric 22:33-38

Holm J, Bjorck I, Drews A, Lund NG (1986) A rapid method for the analysis of starch. Starch-Starke 7:224-226. doi:10.1002/star. 19860380704

Hoskins B, Wolf A, Wolf N (2003) Dry matter analysis. In: Peter J (ed) Recommended methods of manure analysis (A3769). University of Wisconsin Coop. Ext. Publishing Operation, Madison, pp 14-17

Ketterings QM, Klausner SD, Czymmek KJ (2003) Nitrogen guidelines for field crops in New York. Ext. Ser. E03-16. Dep. Crop Soil Sci., Cornell University, Ithaca

Khan SA, Mulvaney RL, Hoeft RG (2001) A simple soil test for detecting sites that are nonresponsive to nitrogen fertilizer. Soil Sci Soc Am J 65:1751-1760. doi:10.2136/sssaj2001.1751

Klapwyk JH, Ketterings QM (2005) Reducing analysis variability of the Illinois soil nitrogen test with enclosed griddles. Soil Sci Soc Am J 69:1129-1134. doi:10.2136/sssaj2004.0231

Klapwyk JH, Ketterings QM(2006) Soil test for predicting corn response to nitrogen fertilizer in New York. Agron J 98:675-681. doi:10.2134/ agronj2005.0241

Klapwyk JH, Ketterings QM, Godwin GS, Wang M (2006) Response of the Illinois soil nitrogen test to liquid and composted dairy manure application in a corn agroecosystem. Can J Soil Sci 86:655-663. doi:10.4141/S05-048

Klausner SD, Guest RW (1981) Influence of $\mathrm{NH}_{3}$ conversion from dairy manure on the yield of corn. Agron J 73:720-723. doi:10.2134/agronj1981.00021962007300040037x

Klausner SD, Reid WS, Bouldin DR (1993) Relationship between late spring soil nitrate concentrations and corn yields in New York. J Prod Agric 6:350-354

Krishnamoorthy U, Muscato TV, Sniffen CJ, Van Soest PJ (1982) Nitrogen fractions in selected feedstuffs. J Dairy Sci 225:217-225. doi:10.3168/jds.S0022-0302(82)82180-2

Lawrence JR, Ketterings QM, Cherney JH, Bossard SE, Godwin GS (2008) Tillage tools for manure incorporation and N conservation. Soil Sci 173:649-658. doi:10.1097/SS.0b013e3181893923

Lawrence JR, Ketterings QM, Goler MG, Cherney JH, Cox WJ, Czymmek $\mathrm{KJ}$ (2009) Illinois soil nitrogen test (ISNT) with organic matter correction for predicting nitrogen responsiveness of corn in rotation. Soil Sci Soc Am J 73:303-311. doi:10.2136/sssaj2007.0440

Littell RC, Milliken GA, Stroup WW, Wolfinger RD (1996) SAS system for mixed models. SAS Inst, Cary

Maguire RO, Kleinman PJA, Dell CJ, Beegle DB, Brandt RC, McGrath JM, Ketterings QM (2011) Manure application technology in reduced tillage and forage systems: a review. J Environ Qual 40:292-301. doi:10.2134/jeq2009.0228

Meisinger JJ, Jokela WE (2000) Ammonia volatilization from dairy and poultry manure. In: Proc. Managing Nutrients and Pathogens from Animal Agriculture, Camp Hill, PA, March 28-30, 2000. NRAES, Ithaca, NY, pp. 334-354

Morgan MF (1941) Chemical soil diagnosis by the universal soil testing system. Connecticut Agric. Ext. Stn. Bull. 450. University of Connecticut, New Haven, CT

Murphy J, Riley JP (1962) A modified single solution method for determination of phosphates in natural waters. Anal Chim Acta 27:31-36. doi:10.1016/S0003-2670(00)88444-5
NRCS (1999) Introduction to crop residue management and conservation tillage. Part 1, pp 1-2. In: NRCS (ed.) Core4 conservation practices training guide: the common sense approach to natural resource conservation. Available at: http://www.nrcs.usda.gov/ Internet/FSE_DOCUMENTS/nrcs143_025540.pdf Verified 9 Feb 2013

Nyiraneza J, Chantigny MH, N'Dayegamiye A, Laverdiere MR (2009) Dairy cattle manure improves soil productivity in low residue rotation systems. Agron J 101:207-214. doi:10.2134/agronj2008.0142

Oregon NRCS (2007) Conservation planning and conservation records: crop residue management. Available at: http://www.or.nrcs. usda.gov/technical/conservation-planning-and-conservation-records/cropresiduemgmt.html Verified 9 Feb 2013

Pierce FJ, Fortin MC, Staton MJ (1994) Periodic plowing effects on soil properties in a no-till farming system. Soil Sci Soc Am J 58:1782-1787. doi:10.2136/sssaj1994.03615995005800060029x

Quincke JA, Wortmann CS, Mamo M, Franti T, Drijber RA, García JP (2007) One-time tillage of no-till systems: soil physical properties, phosphorus runoff, and crop yield. Agron J 99:1104-1110. doi:10.2134/agronj2006.0321

Raper RL (2002) The influence of implement type, tillage depth, and tillage timing on residue burial. Trans ASAE 45:1281-1286

SAS Institute (1998) SAS user's guide: statistics, version 7, 4th edn. SAS Inst, Cary

Sexton B, Metzger B, Nelson V (2005) Performance evaluation of five liquid manure injection systems. Alberta Agriculture, Food and Rural Development Publication. Available at: http:// www1.agric.gov.ab.ca/\$department/deptdocs.nsf/all/agdex10096/ \$FILE/743-1_report.pdf Verified 9 Feb 2013

Shapiro CA, Holshouser DL, Kranz WL, Shelton DP, Witkowski JF, Jarvi KJ, Echtenkamp GW, Lunz LA, Frerichs RD, Brentlinger RL, Lubberstedt MA, McVey McCluskey M, Stroup WW (2001) Tillage and management alternatives for returning conservation reserve program land to crops. Agron J 93:850-862. doi:10.2134/ agronj2001.934850x

Shaver R, Lauer J, Coors J, Hoffman P (2006) Decision software: Milk2006 for corn silage. University of Wisconsin Extension Forage Team, Madison, WI. Available at: http://www.uwex.edu/ ces/crops/uwforage/dec_soft.htm Verified 9 Feb 2013

Shelton DP (2004) Crop residue cover and manure incorporation part II: factors influencing cover reduction. Appl Eng Agric 20:613621

Sirois PK, Reuter MJ, Laughlin CM, Lockwood PJ (1994) A method for determining macro and micro elements in forages and feeds by inductively coupled plasma atomic emission spectrometry. Spectroscopist 3:6-9

Storer DA (1984) A simple high sample volume ashing procedure for determination of soil organic matter. Commun Soil Sci Plant Anal 15:759-772. doi:10.1080/00103628409367515

USDA-National Agricultural Statistics Service (NASS) (2010) New York county data - crops. Available at: http://www.nass.usda.gov/ Data_and_Statistics/Quick_Stats/ Verified 9 Feb 2013

Van Soest PJ, Robertson JB, Lewis BA (1991) Methods for dietary fiber, neutral detergent fiber, and nonstarch polysaccharides in relation to animal nutrition. J Dairy Sci 74:3583-3597. doi:10.3168/jds.S00220302(91)78551-2

Wilhelm WW, Arnold SL, Schepers JS (2000) Using a nitrate specific ion electrode to determine stalk nitrate-nitrogen concentration. Agron J 92:186-189. doi:10.2134/agronj2000.921186x

Wolf A, Beegle B (1995) Recommended soil test for macronutrients: phosphorus, potassium, calcium and magnesium. In: Sims JT, Wolfe A (eds) Recommended soil testing procedures for the northeastern United States. Bulletin 493, NEC-67, 2nd edn. University of Delaware, Newark, pp 30-38 